\title{
The Frustrations of Families: Henry Lynch, Heredity, and Cancer Control, 1962-1975
}

\author{
DAVID CANTOR*
}

When Henry T Lynch thought that he had discovered the existence of hereditary cancers among Nebraskan families in the 1960s, his hope was that it would lead to more effective means of cancer control. Lynch argued that the identification of such cancers offered tremendous opportunities for improving detection and treatment. If cancer ran in families, he claimed, the discovery of a hereditary cancer in one family member should be an alert to the possibility of cancer in others, and so prompt careful scrutiny for any signs that might indicate the presence of the disease in "healthy" individuals. Lynch hoped that by targeting cancer families it would be possible to catch more cancers at an earlier stage than was hitherto possible. Cancers caught early were often curable, the American Cancer Society (ACS) claimed. ${ }^{1}$

Today Lynch is widely regarded as one of the fathers of cancer genetics, notably for his work on hereditary cancers of the breast and colon. However, in the 1960s and 1970s such recognition was a long way away, and few would have predicted his current eminence. Lynch worked (then, as now) at a small, unprestigious Catholic university in Omaha, Nebraska, far from the major centres of cancer research, and his assertions about the hereditary nature of some cancers were not greeted with the enthusiasm he might have wished. Many cancer experts doubted his claim to have identified hereditary cancers, and ACS education efforts routinely stated that cancer was not a hereditary disease. Thus, Lynch's scheme for improving cancer detection and treatment seemed to falter almost before it began. These problems provide an opportunity to examine the relations of heredity to cancer in the 1960s and early 1970s, and what they tell us about cancer control in those years. $^{2}$

(C) David Cantor 2006

* David Cantor, PhD, Division of Cancer Prevention, National Cancer Institute, Executive Plaza North, Suite 2025, Bethesda MD 20892-7309, USA; e-mail: cantord@mail.nih.gov

The research for this paper was supported by the Division of Cancer Prevention (DCP), National Cancer Institute, which provided for both my own work (PO: 263-MQ-216827), and that of my excellent assistant, Raul Necochea (PO: 263-MQ-311650). Jaye Viner, Asad Umar and other members of the DCP Gastrointestinal and other Cancers Research Group were particularly supportive of this project. An earlier version of this paper was given at the History of Medicine Division Brown Bag seminar at the National Library of Medicine, 15th December 2004. The author is grateful to participants at this seminar and to two anonymous referees for comments and suggestions.

\footnotetext{
${ }^{1}$ Robert A Aronowitz, 'Do not delay: breast cancer and time, 1900-1970', Milbank Quarterly, 2001, 79: 355-86.

${ }^{2}$ On cancer control, see ibid.; Barron H Lerner, The breast cancer wars: hope, fear, and the pursuit of a cure in twentieth-century America, New York, Oxford University Press, 2001; and Lester Breslow, et al., A history of cancer control in the United States, with emphasis on the period 1946-1971, prepared by the History of Cancer Control Project, UCLA School of Public Health, pursuant to Contract no. N01-CN-55172, Division of Cancer Control and Rehabilitation, National Cancer Institute, Bethesda, MD, Dept. of Health, Education, and Welfare, Public Health Service, National Institutes of Health, National Cancer Institute, Division of Cancer Control and Rehabilitation, 1977. See also James T Patterson, The dread disease: cancer and modern American culture, Cambridge, MA, and London, Harvard University Press, 1987.
} 


\section{David Cantor}

The fact of heredity's marginality to cancer control in these decades will come as no surprise to readers of this journal. It is well known that research excitement focused on viral and environmental explanations of the disease. ${ }^{3}$ Despite vast programmes of laboratory research on heredity in mice and other animals, ${ }^{4}$ the relatively few studies of heredity in human populations were often greeted with scepticism by cancer experts, who found the association between cancer and heredity unproven or insignificant. ${ }^{5}$ As importantly, I argue, doubts about heredity also focused on the danger it posed to programmes of cancer control. For years cancer experts had sought to wean the public off the belief that cancer was a hereditary disease, fearing that it promoted either complacency or paralytic fear, and so encouraged individuals to delay seeking help until after the best opportunities for effective treatment were gone. To his critics, Lynch's focus on hereditary cancers threatened to perpetuate these problems, and consequently to undermine the very programmes of control that he sought to improve.

If Lynch's advocacy of heredity reveals concerns about the impact of hereditarian beliefs on the public, it also reveals divisions over the moral responsibility for seeking care. Robert Aronowitz has noted that the "do not delay" message of control programmes tended to make individual patients responsible for obtaining help for their cancer, while at the same time minimizing the responsibility of physicians. ${ }^{6}$ Lynch's approach highlights an alternative moral universe that saw individual choice restricted by powerful psychodynamic forces, and that placed greater responsibility on the physician for ensuring that the cancer control message got through. In his view, many physicians failed to address patients' emotional needs, and so tended to exacerbate the fear and stigma associated with cancer, thus contributing to the problems of delay and what would come to be known as compliance. ${ }^{7}$ Lynch's efforts to shift responsibility, I argue, emerged out of a peculiar

\footnotetext{
${ }^{3}$ Robert N Proctor, Cancer wars: how politics shapes what we know and what we don't know about cancer, New York, Basic Books, 1995; Stephen P Strickland, Politics, science and dread disease: a short history of United States medical research policy, Cambridge, MA, Harvard University Press, 1972.

${ }^{4}$ Ilana Löwy and Jean-Paul Gaudillière,

'Disciplining cancer: mice and the practice of genetic purity', in Jean-Paul Gaudillière and Ilana Löwy (eds), The invisible industrialist: manufactures and the production of scientific knowledge, Basingstoke, Macmillan, 1998, pp. 209-49; Jean-Paul Gaudillière, 'Circulating mice and viruses: the Jackson Memorial Laboratory, the National Cancer Institute, and the genetics of breast cancer, 1930-1965', in Michael Fortun and Everett Mendelsohn (eds), The practices of human genetics, Dordrecht, Kluwer Academic Publishers, 1999, pp. 89-124; Jean-Paul Gaudillière, 'Making heredity in mice and men: the production and uses of animal models in postwar human genetics', in Jean-Paul Gaudillière and Ilana Löwy (eds), Heredity and infection: the history of disease transmission, London and New York, Routledge, 2001, pp. 181-202; Jean-Paul Gaudillière, 'Mapping as technology: genes, mutant mice, and biomedical research (1910-1965)',
}

in Hans-Jörg Rheinberger and Jean-Paul Gaudillière (eds), Classical genetic research and its legacy: the mapping cultures of twentieth-century genetics, London and New York, Routledge, 2004, pp. 173-203; Karen A Rader, Making mice: standardizing animals for American biomedical research, 1900-1955, Princeton and Oxford, Princeton University Press, 2004, esp. chs 4 and 5.

${ }^{5}$ For one of the few exceptions to the dismissal of hereditarian explanations of cancer, see Paolo Palladino, 'Between knowledge and practice: on medical professionals, patients, and the making of the genetics of cancer', Soc. Stud. Sci., 2002, 32: 137-65. See also Paolo Palladino, 'Speculations on cancer-free babies: surgery and genetics at St. Mark's Hospital, 1924-1995', in Gaudillière and Löwy (eds), Heredity and infection, op. cit., note 4 above, pp. 285-310; and Paolo Palladino, Plants, patients and the historian: (re)membering in the age of genetic engineering, New Brunswick, NJ, Rutgers University Press, 2003.

${ }^{6}$ Aronowitz, op. cit., note, 1 above, esp. pp. 370-5.

${ }^{7}$ Jeremy A Greene, 'Therapeutic infidelities: 'noncompliance' enters the medical literature, 1955-1975', Soc. Hist. Med., 2004, 17: 327-43. 


\section{Henry Lynch, Heredity, and Cancer Control, 1962-1975}

intersection of cancer, medical genetics and psychology that located problems of delay and compliance in patterns of social-especially family-interactions much more than in the biological or psychological characteristics of an individual. ${ }^{8}$ From such a perspective, families could be the frustration of cancer control.

\section{Henry T Lynch}

Henry T Lynch was born in Lawrence, Massachusetts, on 4 January 1928. ${ }^{9}$ He grew up in a poor section of New York City, dropped out of school at the age of fourteen, and, in 1944, tricked his way into the US Navy, using a cousin's identification to make himself seem older than his sixteen years. The subterfuge was discovered, but the Navy kept him on for the duration of the Second World War. He served in Europe, and participated in the liberation of the Philippines, but most of the time he ploughed the Pacific as a gunner on a merchant marine ship. Discharged from the Navy in 1946, he became a professional boxer, working predominantly in upper New York State and the San Francisco Bay area. After this unusual beginning for a physician, he began training in the three areas that would dominate his professional life in the 1960s and 1970s-psychology, genetics and medicine.

Lynch took a qualifying examination to complete his high school requirements, and went to the University of Oklahoma in Norman aiming to become a clinical psychologist. Graduating in 1951, he moved to the University of Denver in 1952 where he took a masters degree in clinical psychology. He then began a PhD at the University of Texas, Austin (1953-1956), majoring in human genetics (with minors in biochemistry and psychology) under Clarence P Oliver (1898-1991), the one-time founder and director of the Dight Institute for Human Genetics at the University of Minnesota. ${ }^{10}$ Abandoning the PhD,

\footnotetext{
${ }^{8}$ For the background of post-war enthusiasm for psychology, see Nathan G Hale Jr, The rise and crisis of psychoanalysis in the United States: Freud and the Americans, 1917-1985, New York, Oxford University Press, 1995; Ellen Herman, The romance of American psychology: political culture in the age of experts, Berkeley, University of California Press, 1995; Eva S Moskowitz, In therapy we trust: America's obsession with self-fulfillment, Baltimore, Johns Hopkins University Press, 2001; Joel Pfister and Nancy Schnog (eds), Inventing the psychological: toward a cultural history of emotional life in America, New Haven, Yale University Press, 1997.

${ }^{9}$ I am grateful to Dr Lynch for a copy of his CV. An earlier version of his CV is available at $<$ http://tobaccodocuments.org/ctr/CTRMN011133-1160. html $>$ (accessed 18 July 2003). Details of his career are also obtained from < http://www.whonamedit.com/ doctor.cfm/1970.html > (accessed 18 July 2003), and from Eugene P DiMagno, 'Lifetime Achievement Award Henry T. Lynch, MD. International Symposium on Inherited Diseases of the Pancreas', in Peter Durie, Markus M Lerch, Albert B Lowenfels, Patrick Maisonneuve, Charles D Ulrich and David C Whitcomb (eds), Genetic disorders of the exocrine pancreas: an overview and update, Basel, Karger, 2002, pp. 149-53; 'Henry Lynch's family affair: on the
}

trail of inherited cancers', Coping Magazine, May 1987, pp. 50-4; Mary McGrath, 'Dr. Henry T. Lynch', Sunday World Herald [Omaha], 28 Nov. 1999, Section R, p. 24. Details of his career are also from an interview I conducted with Henry Lynch, 12th December 2003, in his office at Creighton University, hereafter 'Lynch interview, 12th December 2003'.

${ }^{10}$ Oliver moved to Austin in 1946, where he established a human genetics programme at the University of Texas and served as chair of the department of zoology. Clarence P Oliver, 'Human genetics program at the University of Texas', Eugenical News, 1952, 37: 25-31. It is possible that Lynch's first contact with human or medical genetics was during his time at Oklahoma where Lawrence H Snyder and Paul R David provided genetic advice to families referred to them. Snyder had been professor in medical genetics at Ohio State University before moving in 1947 to become Dean of the Graduate College of the University of Oklahoma. David was the Professor of Zoology also at the University of Oklahoma. Daniel J Kevles, In the name of eugenics: genetics and the uses of human heredity, Cambridge, MA, Harvard University Press, 1995, pp. 209-10. For a listing of North American counselling centres in the 1950s, see Lee R Dice, 'Heredity clinics: their value for public service and for research', American Journal of 


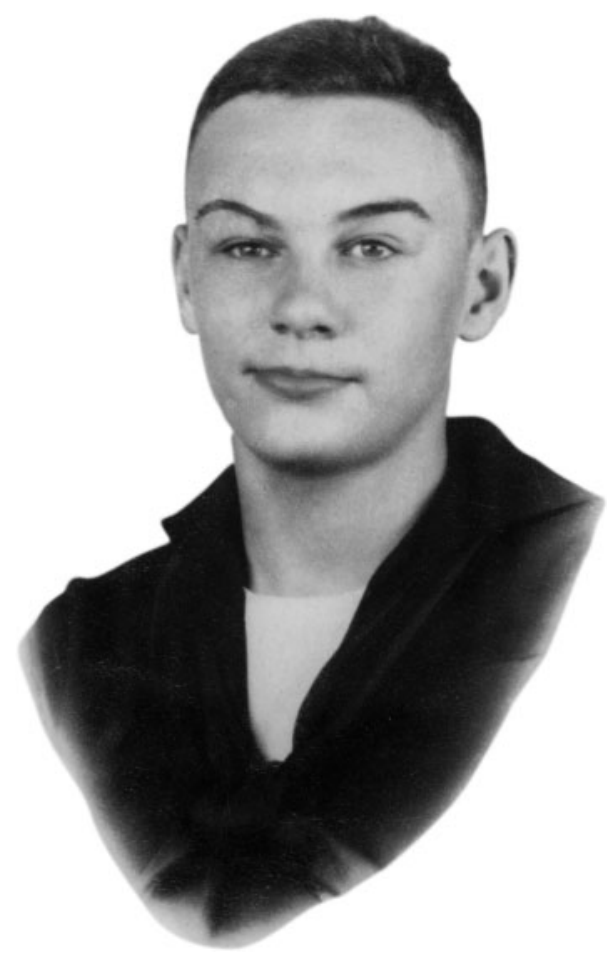

Figure 1: Henry Lynch as a young man. Undated photograph, probably taken in the 1940s. (Henry Lynch archives. Reprinted with permission of Henry Lynch.)

Lynch went on to study medicine at the University of Texas, Galveston, from where he graduated in 1960. In succession he was an intern at St Mary's Hospital, Evansville, Indiana (1961); a resident in internal medicine at the University of Nebraska College of Medicine, Omaha (1961-1964); and a USPHS fellow in clinical oncology at the Eppley Institute for Research in Cancer and Allied Diseases, Omaha (1964-1966), during which time he also held various lecturing positions in Lincoln, Nebraska. ${ }^{11}$ A brief appointment followed as Assistant Professor of Biology and Assistant Internist in Medicine (Human Genetics, and Medical Oncology) at the University of Texas, MD Anderson Hospital and

Human Genetics, 1952, 4: 1-13. A shorter version of this article is available in Lee R Dice, 'Counseling centers on human heredity in North America', Eugenical News, 1952, 37: 32-34.

${ }^{11}$ These positions were: Medical Genetics Consultant and Lecturer, Department of Orthodontics,
University of Nebraska College of Dentistry, Lincoln (1962-1965), and Lecturer in Human Genetics, Graduate and undergraduate students, Department of Zoology, University of Nebraska, Lincoln (1962-1964). 
Henry Lynch, Heredity, and Cancer Control, 1962-1975

Table 1

Henry T Lynch's appointments at Creighton University, 1967-1975.

$1967-1968$

$1968-1970$

1970-present
Assistant Professor of Medicine, Creighton University

School of Medicine

Associate Professor and Chairman, Department of Preventive

Medicine, Creighton University School of Medicine

Professor and Chairman, Department of Preventive Medicine,

Creighton University School of Medicine

Tumor Institute in Houston (1966-1967). Then in 1967, he joined the faculty of the Creighton University School of Medicine, Omaha, Nebraska, where he remains today. ${ }^{12}$

Lynch might have trained in human genetics, but his main interest was in its clinical applications, what he labelled "medical genetics", a specialty that had emerged in the late 1950 s as institutionally distinct from human genetics. ${ }^{13}$ While in Galveston in the late 1950s he helped set up a clinical genetics programme in the departments of Pediatrics and Anatomy at the University of Texas Medical Branch, along with the paediatrician, Robert L Tips, and the anatomist, C Wallace McNutt. ${ }^{14}$ From 1959, McNutt continued the programme in the Anatomy Department at Galveston. Tips left for the University of Oregon Medical School in Portland, where he developed a similar programme in cooperation with a physician at the Oregon Fairview Home, George S Smith, after which both he and Smith returned to Texas, to the Pediatrics Department at the Baylor Medical School in Houston. ${ }^{15}$ Lynch himself moved to Nebraska, where he established a medical genetics clinic at the University of Nebraska, College of Medicine. In 1964, Lynch took the 'Short

\footnotetext{
${ }^{12}$ Lynch notes that he was invited to Creighton by the medical school dean, Richard Egan. 'Lynch interview, 12th December 2003', op. cit., note 9 above. On Lynch's appointment, see Wayne B Leadbetter, 'Dr. Lynch takes over', The Beat, SMA, The Creighton University, Nov. 1967, 1 (2): 1, 7; 'Two new department heads named', Creighton Faculty Newsletter, Nov. 1967: 3; John M McBride, 'Boxing, research in cancer both part of doctor's career', The Creightonian, 27 Oct. 1967: 9; 'Noted cancer researcher heads medical department', The Creightonian, 17 Nov. 1967; 'Named head at Creighton', Diagnosis News, March 1968, 1 (3): 24; 'Authority on cancer genetics to head Creighton's preventive medicine unit', West Omaha and Dundee Sun, 2 Nov. 1967.

${ }^{13}$ Kenneth M Ludmerer, Genetics and American society: a historical appraisal, Baltimore and London, Johns Hopkins University Press, 1972, pp. 190-3. See also Kevles, op. cit. note 10 above; Diane B Paul, The politics of heredity: essays on eugenics, biomedicine, and the nature-nurture debate, Albany, State University of New York Press, 1998, pp. 133-56. For
}

British and Canadian perspectives, see, respectively, Peter Coventry and John Pickstone, 'From what and why did genetics emerge as a medical specialism in the 1970s in the UK?', Soc. Sci. Med., 1999, 49: 1227-38; William Leeming, 'Ideas about heredity, genetics, and "medical genetics" in Britain, 1900-1982', Stud. Hist. Phil. Biol. \& Biomed., 2005, 36: 538-58; and William Leeming, 'The early history of medical genetics in Canada', Soc. Hist. Med., 2004, 17: 481-500. In addition on human genetics, see Fortun and Mendelsohn, op. cit., note 4 above.

${ }^{14}$ For details of this clinic, see the note in Robert $\mathrm{L}$ Tips, George S Smith, Henry T Lynch and C Wallace McNutt, "The "whole family" concept in clinical genetics', Am. J. Dis. Child., 1964, 107: 67-76, p. 67. For a history of the University of Texas Medical Branch, see Chester R Burns, Saving lives, training caregivers, making discoveries: a centennial history of the University of Texas Medical Branch at Galveston, Austin, Texas State Historical Association, 2003.

${ }^{15}$ In 1964, Tips listed his affiliation as Department of Pediatrics, Baylor Medical School, Houston. 


\section{David Cantor}

Course in Medical Genetics' organized annually since 1959 by Victor McKusick for the National Science Foundation at Bar Harbor in Maine. ${ }^{16}$

Lynch's vision of medical genetics revolved around what he called the "medical genetics research team". ${ }^{17}$ In Nebraska, this team initially comprised Lynch himself, a social worker, Anne Krush, some medical students, and consultants from the clinical and basic science departments of the College of Medicine in Omaha and the College of Dentistry in Lincoln, all supported by a network of referring physicians. Founded in 1961, the team aimed to study the various hereditary diseases recorded in the state of Nebraska, and to determine their geographic concentration through maps of incidences of these diseases. ${ }^{18}$ Lynch claimed that, with its predominantly rural population, Nebraska was ideally suited for genetic investigations such as he proposed. Rural families, he noted, kept careful records of their kindred, and often several generations of the family would live within close proximity to each other, so facilitating researchers' contacts with them. Lynch also noted what he called "a deep-seated pioneering tradition and philosophy in support of worthwhile pursuits" "19 among Nebraskans that made them particularly willing to help in his investigations.

The cooperation of patients and their families was central to Lynch's efforts to identify genetic diseases. According to Lynch, patients and members of the family were first interviewed by him for information on the major manifestations of the disease in the patient and in other members of the family. ${ }^{20}$ They would be asked about marriage, extramarital children and the possible presence of consanguity in ancestors. Lynch stated that he would construct a family pedigree in collaboration with the patient, asking him or her for information on marriage, paternities, surnames, maiden names, birth dates, pregnancy histories (with careful exploration for exposures to viral and bacterial infections, drugs and other uterine environmental hazards) and manifestations of the disease in relatives. Patients would be asked about the presence of other genetic diseases, and about feuds and other intra-family conflicts to obviate future problems. Lynch stated that he would review with the patient the objects of the investigation, questionnaires that might be sent to other members of his or her family, and he would try to obtain permissions forms.

\footnotetext{
${ }^{16}$ Lynch's CV at <http://tobaccodocuments.org/ ctr/CTRMN011133-1160.html>, op. cit., note 9 above. On the Bar Harbor course, see Ludmerer, op. cit., note 13 above, p. 191.

${ }^{17} \mathrm{H}$ T Lynch, Anne Krush and Rose Faithe, 'Medical genetics in Nebraska', Nebr. State Med. J., 1964, 49: 406-11. On the establishment of a genetics clinic, see H T Lynch, 'Heredity, cancer, and the genetics clinic', Texas Medicine, 1967, 63: 57-61.

${ }^{18}$ Among the sixteen types of diseases the team studied were Dercum's disease, transposition of the great vessels, osteogenesis imperfecta, cystinosis, dwarfism, diabetes, hypothyroidism, pulmonary emphysema, and several (unspecified) forms of cancer.

${ }^{19}$ Lynch, Krush and Faithe, op. cit., note 17 above, p. 411. Contrast this with the secrecy that McKusick
}

found a problem among the Amish. M Susan Lindee, 'Provenance and the pedigree: Victor McKusick's field work with the old order Amish', in Alan H Goodman, Deborah Heath and M Susan Lindee (eds), Genetic nature/culture: anthropology and science between the two-culture divide, Berkeley, University of California Press, 2003, pp. 41-57. A revised version of Lindee's article on McKusick has been published as chapter 3 of her Moments of truth in genetic medicine, Baltimore, Johns Hopkins University Press, 2005, pp. 58-89. On the history of rural Nebraska families, see Deborah Fink, Agrarian women: wives and mothers in rural Nebraska, 1880-1940, Chapel Hill and London, University of North Carolina Press, 1992.

${ }^{20}$ Lynch, Krush and Faithe, op. cit., note 17 above, esp. p. 407. 


\section{Henry Lynch, Heredity, and Cancer Control, 1962-1975}

Anne Krush, Lynch's social worker, was crucial to his efforts to secure the cooperation of patients. Born on 27 June 1914 in Sewickley, Pennsylvania, Krush had graduated from Wellesley College in 1936, before enrolling in the Western Reserve University School of Medicine in Cleveland, one of only two women that year. After completing two years of medical school, she transferred to the Western Reserve University School of Applied Social Sciences, from where she graduated in 1941 with a Master of Science in Social Administration. Her first job was as a medical social worker in Pittsburgh, after which she moved to Massachusetts General Hospital in 1946, and then to Omaha, Nebraska. In 1961 she joined Lynch's medical genetic research team as a research social worker in medical genetics at the College of Medicine. She accompanied Lynch to the MD Anderson Hospital in Houston, where she held a position as a Research Associate in Medical Genetics, returning (like Lynch) to Omaha in 1967 to become an Assistant Professor of Medicine at Creighton University. As part of Lynch's team, Krush would obtain information from social agencies with which the family was involved; explore issues such as the emotional response of family members to the "family disease"; and investigate the needs of the family for future agency or community welfare or rehabilitation. ${ }^{21}$

In the case of cancer, Lynch and Krush were particularly impressed at the knowledge that these families had of the disease. Many family members, they noted, seemed extraordinarily knowledgeable about the incidence and transmission of cancer in the family. ${ }^{22}$ These individuals, they claimed, were not knowledgeable of the general principles of human genetics, yet they were able to make statements strongly implicating the likelihood of hereditary factors, repeatedly referred to themselves as being part of a cancer family, and so provided important clues for physicians to identify hereditary cancers. Not only did they provide clues as to the identification of hereditary cancers, they also provided an opportunity to explore popular attitudes and feelings towards such diseases. ${ }^{23}$ Lynch and Krush noted, for example, that the genealogical records kept by one family set the stage for much internal family discussion about the "family disease", particularly among those individuals in the direct blood line who where approaching cancer risk ages. In the course of field visits, Lynch and his colleagues used the offices of a private family physician to stage what they called a "family reunion", ${ }^{24}$ which provided the opportunity for individuals not only to comment on the "family tree" (or pedigree), but also for Lynch and his colleagues to begin to study the responses of individuals towards cancer. ${ }^{25}$

\footnotetext{
${ }^{21}$ Ibid. Biographical information on Krush is taken from, 'The Anne J. Krush Fund for Education and Research in Hereditary Colorectal Cancer Syndromes', $<$ http://hopkins-gi.nts.jhu.edu/pages/latin/giving/ annekrush.cfm $>$ (accessed 17 April 2005).

${ }^{22}$ Anne J Krush, Henry T Lynch and Charles Magnuson, 'Attitudes toward cancer in a "cancer family": implications for cancer detection,' Am.J. Med.Sci., 1965, 249: 432-8. One of the clues to the identification of his first cancer family came from his first CFS patient, who explained that he drank excessively because he knew he would one day die of cancer, like all members of his family. Henry T Lynch, Thomas Smyrk, and Jane F Lynch, 'Molecular genetics and clinical-pathology features of hereditary
}

nonpolyposis colorectal carcinoma (Lynch syndrome): historical journey from pedigree anecdote to molecular genetic confirmation', Oncology, 1998, 55: 103-8, p. 104.

${ }^{23}$ Krush, Lynch and Magnuson, op. cit., note 22 above.

${ }^{24}$ Ibid., p. 433.

${ }^{25}$ Ibid., p. 434. See also the movie, The family tree. Cancer genetics: guide to early diagnosis, University of Texas MD Anderson Hospital and Tumor Institute at Houston and the Richardson Foundation, produced by Medical Communications, Houston, University of Texas, 1967. Copy available in National Library of Medicine (QZ 241 VC no.2 1967). 


\section{David Cantor}

If family members were important to the identification of genetic diseases, they were also a problem. Individuals had faulty memories, and limited knowledge of the real nature of disease. They did not know the secrets of other members of the family, and the records they provided-bibles, photographs, diaries and so on-had limited value in identifying specific diseases. As McKusick had found earlier, all this raised questions about the reliability of knowledge produced from such sources. ${ }^{26}$ Thus, Lynch and Krush supplemented the interviews with evidence from other sources: medical records, historical archives, libraries, census data, and the records of genealogical societies. ${ }^{27}$ They would also supplement patients' records and recollections with histological observations and autopsy material. Lynch and Krush contrasted the certainty of the results achieved by such a combination of interview and pathological observation favourably with pedigrees based on unconfirmed reports and rumours - a characteristic, he claimed, of earlier human genetics studies. Their approach was, they noted, "in keeping with modern medical genetics research as opposed to earlier studies in human genetics where emphasis was placed upon history alone with pedigree construction resting predominantly on hearsay evidence." 28 Lynch also contrasted it with what he called "bizarre misconceptions based on folklore and old wives' tales" 29 that families might harbour and offer as causes for the occurrence of particular lesions. In such ways, Lynch and Krush sought to distance medical genetics both from human genetics and from popular understandings of disease and heredity.

\section{Family Cancers}

Lynch's interest in cancer and heredity began shortly after his arrival in Omaha. He recounts that in 1962 or 1964 Charles Magnuson, a gastroenterologist at the Omaha Veterans Administration Hospital, requested that he consult on a patient with a strong family history of colorectal cancer. ${ }^{30}$ Magnuson felt that familial adenomatous polyposis (FAP) was most likely the problem in the family, since FAP was the only known hereditary disorder predisposing to colorectal cancer. ${ }^{31}$ However, when Lynch and Krush drew up a detailed pedigree, they found a strong predilection for colorectal cancer, but in the absence of multiple colonic polyps. Lynch presented his findings at a meeting of the American

\footnotetext{
${ }^{26}$ Lindee, op. cit., note 19 above.

${ }^{27}$ Lynch's interest in collecting such information led him to criticize the common hospital practice of destroying old medical records, see Henry T Lynch and Anne J Krush, 'The life and death of medical records', JAMA, 7 December 1970, 214: 1890. p. 410 .

${ }^{28}$ Lynch, Krush and Faithe, op. cit., note 17 above,

${ }^{29}$ Henry T Lynch, 'Skin, heredity and cancer', Cancer, 1969, 24: 277-88, p. 286.

${ }^{30}$ Lynch, Smyrk, and Lynch, op. cit., note 22 above; Alan G Thorson, Joseph A Knezetic and Henry T Lynch, 'A century of progress in hereditary
}

nonpolyposis colorectal cancer (Lynch Syndrome)', Diseases of the Colon and Rectum, 1999, 42: 1-9. Details of the work can be found in the 'Family register' compiled by Lynch for members of Family N. in 1978, Papers held by Henry Lynch at the Creighton University (hereafter Lynch archives). The register states that the first patient was referred in 1964, the others state 1962.

${ }^{31}$ On FAP, see Palladino, 'Between knowledge and practice’, op. cit., note 5 above. See also Palladino, 'Speculations on cancer-free babies' and Palladino, Plants, patients and the historian, both op. cit., note 5 above. 


\section{Henry Lynch, Heredity, and Cancer Control, 1962-1975}

Society of Human Genetics in 1964. The story goes that his presentation reminded Marjorie Shaw, a medical geneticist at the University of Michigan (Ann Arbor), of another family with similar genetic and clinical manifestations. In 1966, she, Lynch, Krush, Magnuson and Arthur L Larsen, a pathologist at the University of Nebraska Medical Center, published their first report on the two families-family $\mathrm{N}$ from Nebraska, and family $\mathrm{M}$ from Michigan. ${ }^{32}$ It was the beginning for Lynch of a long-standing interest in what would come to be known as "cancer family syndrome" (CFS) $)^{33}$ —now "hereditary non-polyposis colorectal cancer" (HNPCC) or "Lynch's syndrome". 34

Lynch tells the story of the beginnings of his interest in CFS as one of happenstance. But, if it happened by chance, it happened to someone who had already thought about hereditary cancers and how they might be studied. In the 1950s and early 1960s, Lynch's former mentor in Austin, Clarence Oliver, was one of a small number of researchers that began to explore the role of heredity in human cancers. Until then, the bulk evidence of such cancers had come from experimental research on laboratory animals, especially mice. ${ }^{35}$ By contrast, Oliver and other geneticists turned to human populations to study the role of heredity in a variety of cancers such as the breast, stomach, colon, and prostate, as well as the leukaemias and lymphomas. Oliver, for example, used family studies to research the hereditary contribution to risk of breast cancer, concluding that close relatives of breast cancer patients had an increased risk of developing the disease, which he attributed to shared genes. ${ }^{36}$ Thus, when Lynch identified his first case of a familial predilection towards colorectal cancer in the absence of colonic polyps, he was building on a growing number of family studies that explored the hereditary nature of the disease. Indeed, his medical genetics research team was also identifying a number of other familial malignancies in Nebraska, including cancers of the breast, stomach and prostate. ${ }^{37}$ It was probably the work of this team that prompted Magnuson to turn to Lynch for help with his colorectal patient.

${ }^{32}$ H T Lynch, M W Shaw, C W Magnuson, A L Larsen, and A J Krush, 'Hereditary factors in cancer: study of two large midwestern kindreds', Arch. Intern. Med., 1966, 117: 206-12.

${ }^{33}$ Ibid. Lynch described CFS as a pedigree involving a high occurrence of adenocarcinomas of multiple anatomical sites (most frequently in the endometrium and colon), multiple primary malignant neoplasms, an early age at onset, and autosomal dominant inheritance. He contrasted this with familial occurrences of malignancy, which by and large were concerned with cancer of specific anatomic sites such as the breast, stomach, prostate, and colon.

${ }^{34}$ The term "hereditary nonpolyposis colon cancer" was used by Lynch in 1981. Henry T Lynch, William Albano, James Recerbaren, Patrick M Lynch, and Jane F Lynch, 'Prolonged survival as a component of a hereditary breast and nonpolyposis colon cancer', Medical Hypotheses, 1981, 7: 1201-9, p. 1202; H T

Lynch, G J Voorhees, S J Lanspa, P S McGreevy and J F Lynch, 'Pancreatic carcinoma and hereditary nonpolyposis colorectal cancer: a family study', $B r . J$. Cancer, 1985, 52: 271-3.

${ }^{35} \mathrm{On}$ animal research and human genetics, see Gaudillière, 'Circulating mice and viruses', and 'Making heredity in mice and men', both op. cit., note 4 above. But see Palladino for earlier studies of human cancers, 'Between knowledge and practice', op. cit., note 5 above. See also Palladino, 'Speculations on cancer-free babies', and Plants, patients and the historian, op. cit., note 5 above.

${ }^{36} \mathrm{C}$ P Oliver, 'Studies on human cancer families', Ann. N. Y. Acad. Sci., 1958, 71: 1198-212; Clarence P Oliver, 'Genetic factors in breast cancer', Proceedings of the National Cancer Conference, 1964, 5: 133-42; Clarence P Oliver, 'Formal discussion of: cancer in man', Cancer Research, 1965, 25: 1327-29.

${ }^{37}$ Lynch, Krush and Faithe, op. cit., note 17 above. This was his first published account in which he indicated that cancer was one of the many hereditary conditions he was studying that deserved more focused attention. 


\section{David Cantor}

The idea that people might be hereditarily predisposed to cancer was not new. Nineteenth- and early-twentieth-century physicians routinely wrote about a predisposition towards disease acquired through heredity, or through the insults to the body accumulated over a lifetime, or through some combination of both. ${ }^{38}$ What was different about the notion of heredity that Oliver, Lynch and other geneticists employed was-as Lynch himself noted ${ }^{39}$ - the use of statistics to identify the genetic nature of the predisposition. In such studies, researchers would examine large populations affected with the disease, analyse the "relative risks" for various factors such as sex or the number of family relatives with the disease, and then draw conclusions about their roles in promoting cancer. ${ }^{40}$ The link between heredity and cancer, therefore, tended to be expressed in terms of frequency or probability. For example, Lynch characterized CFS as involving-among other factors - an increased frequency of adenocarcinomas, particularly adenocarcinomas of the colon and endometrium, and an increased frequency of multiple primary malignant neoplasms. Individuals in cancer families, Lynch claimed, had a greater probability of succumbing to these cancers than the population at large, though they did not have a greater probability of succumbing to other types of cancer. CFS was, therefore, probably a genetic disease, he noted, and the genotype was probably specific to $\mathrm{CFS}^{41}$

Lynch may have been persuaded that CFS was hereditary, but others were not. Critics suggested that he had not taken adequate account of environmental or viral factors in his studies of cancer families. Thus, in the late 1960s - as Lynch relates the story-an NIH site-team expressed strong doubts about his claims for the genetic basis of CFS. In its view, Lynch had not conclusively demonstrated that CFS families were the product of heredity: they could be chance clusters of cancer, or due to common environmental exposures, or the result of ascertainment bias. The site-team advised him to look for common environmental factors in the rural families he studied. ${ }^{42}$ Others targeted his pathological work as

\footnotetext{
${ }^{38}$ For a discussion of proximate, remote, predisposing and exciting causes, see Christopher Hamlin, 'Predisposing causes and public health in early nineteenth-century medical thought', Soc. Hist. Med., 1992, 5: 43-70. Michael Worboys, Spreading germs: disease theories and medical practice in Britain, 1865-1900, Cambridge and London, Cambridge University Press, 2000. See also Robert Olby, 'Mendelism and the theory of hereditary diathesis', Proceedings of the Symposium on the History of Human Genetics, International Congress of Human Heredity, Washington DC, 1991, published in K R Dronamraju (ed.), The history and development of human genetics, Singapore, World Scientific, 1992, pp. 256-65; W F Bynum, 'Darwin and the doctors: evolution, diathesis, and germs in 19th-century Britain', Gesnerus, 1983, 40: 43-53.

${ }^{39} \mathrm{H}$ T Lynch and A J Krush, 'Heredity and breast cancer: implications for cancer control', Med. Times, 1966, 94: 599-605, p. 602.
}

\footnotetext{
${ }^{40}$ V Elving Anderson, Harold O Goodman, Sheldon $\mathrm{C}$ Reed, Variables related to human breast cancer, Minneapolis, The University of Minnesota Press, 1958. For a history of the risk factor, see William G Rothstein, Public health and the risk factor: a history of an uneven medical revolution, Rochester, NY, University of Rochester Press, 2003.

${ }^{41}$ For a statement of such arguments in relation to other hereditary cancers and that no genotype seemed to lead to all cancers in general, see Curt Stern, Principles of human genetics, 2nd ed., San Francisco and London, Freeman, 1960, p. 566.

${ }^{42}$ Lynch, Smyrk, and Lynch, op. cit., note 22 above. I have been unable to find any records of this visit in $\mathrm{NIH}$ or NCI records or archives. For a discussion of statisticians' attempts to eliminate bias in clinical trials, see Harry M Marks, The progress of experiment: science and therapeutic reform in the United States, 1900-1990, Cambridge University Press, 2997, esp. pp. 144-6.
} 


\section{Henry Lynch, Heredity, and Cancer Control, 1962-1975}

problematic. Lynch recalls an incident at a European meeting when an unnamed ${ }^{43}$ gastrointestinal pathologist informed him that CFS families were simply FAP with inadequate pathologic study. To Lynch's embarrassment, the pathologist was proved right in one case. One of the first alleged CFS families was later shown to have an attenuated variant of FAP. ${ }^{44}$

In Lynch's view, the attack on CFS was but one instance of a broader assault on studies that pinpointed heredity as a significant cause of human cancers. Echoing the plaints of many medical geneticists, he claimed that critics routinely sought to dismiss such studies by suggesting that results were distorted by problems of data collection and analysis, as when they pointed to issues of the adequacy of pathologic study or ascertainment bias. They also sought to dismiss such studies by suggesting that their failure to find classical Mendelian patterns of inheritance in all but a handful of cancers undermined claims for a significant role for heredity. The major cancers of the breast, colon, stomach, endometrium, prostate and lung were often associated with an increase in risk to relatives of individuals blighted by such diseases. Yet none exhibited a simple genetic inheritance pattern, and so allowed for the possibility that other factors might be at work besides heredity. Few critics would have suggested that heredity had no role in cancer; just that it had no significant role.

Frustrated with his critics, Lynch was moved to label them so unsophisticated in medical genetics as to "expect a definite [Mendelian] genetic pattern in human family histories, or otherwise ... discredit genetics as one factor in cancer development." 45 (This claim of unsophistication was made despite the fact that the NIH site team mentioned above included what Lynch later called "distinguished" geneticists and epidemiologists. ${ }^{46}$ ) Patterns of inheritance might be there awaiting discovery, he suggested, but the natural history of the disease and methodological problems of human genetics got in the way of discovery. For example, in the case of breast cancer he noted that the late stage of onset and the lack of complete ascertainment of relatives could obscure the recognition of simple genetic inheritance (a claim that may have confirmed his critics in their concerns that his methods distorted his results.) Equally problematic, in Lynch's view, was the possibility that environmental and other extra-genetic factors might work against the discovery of such patterns of inheritance. Quoting his former mentor, Clarence Oliver, Lynch speculated that in the case of breast cancer the high frequency of solitary cases might be due to the existence of two groups of causes of cancer, one hereditary, one environmental. These patterns, he suggested, might be due to an inter-relationship between genes

\footnotetext{
${ }^{43}$ In interview Lynch is very reluctant to name his critics, and they seem to have been equally reluctant to put their doubts about him into print. Lynch noted that he did not wish to embarrass his former critics by naming them. 'Lynch interview, 12th December 2003', op. cit., note 9 above.

${ }^{44}$ Lynch, Smyrk, and Lynch, op. cit., note 22 above, p. 105.

${ }^{45}$ Lynch and Krush, op. cit., note 39 above, pp. 600-601. Lynch's comment was itself a quotation from Oliver, 'Formal discussion', op. cit., note 36 above, p. 1327. Note that Oliver's comment refers to lay
}

misunderstandings of genetics, while Lynch's comment can be read to refer to medical misunderstandings. On the importance of Mendelism to medical genetics, see Jean-Paul Gaudillière, 'Mendelism and medicine: controlling human inheritance in local contexts, 1920-1960', Comptes Rendus de l'Académie des Sciences. Série III, Sciences de la Vie, 2000, 323: 1117-26. Olby, op. cit., note 38 above.

${ }^{46}$ Lynch, Smyrk, and Lynch, op. cit., note 22 above, p. 104 . 


\section{David Cantor}

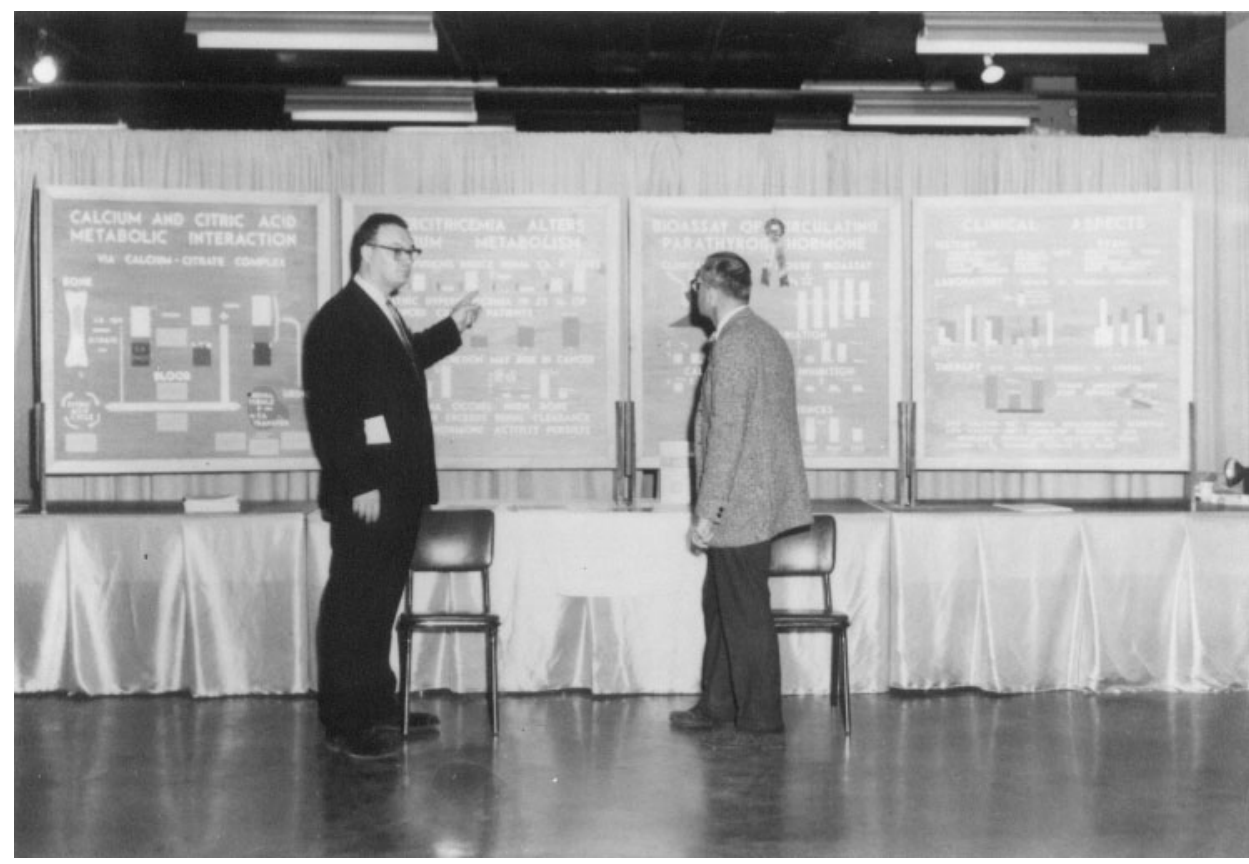

Figure 2: Today, Henry Lynch is a leading figure in cancer genetics, his numerous papers presented to packed conferences. This was not always the case. In the 1960s and 1970s, Lynch's audiences could be significantly smaller. Henry Lynch (left) and an unidentified individual at a poster session. Undated photograph, probably late 1960s/early 1970s. (Henry Lynch archives. Reprinted with permission of Henry Lynch.)

and an unknown environmental agent in which the gene may be present but unexpressed unless the proper environment coexisted. ${ }^{47}$

Such arguments, however, did not persuade his detractors, and Lynch found himself preaching in a wilderness of doubt. Lynch argued that the impact of genetics on the body and disease was always dependent on an interplay of genetics with environmental and social factors. The genetic constitution of an individual was, he claimed, "an instrument played upon by a variable environmental symphony", ${ }^{48}$ that included viruses, tobacco, aniline dyes, coal tar, hydrocarbons, radiation, nitrogen mustards, and other carcinogens. He also noted that national and ethnic differences such as occupations, industrial exposures, food habits, climate, sexual customs, breast-feeding, and fecundity might be

\footnotetext{
${ }^{47}$ Lynch and Krush, op. cit., note 39 above, p. 603. The original comments are in Oliver, 'Studies on human cancer families', op. cit., note 36 above. Then again, in the case of CFS, the non-Mendelian character of the segregation ratio in some sibships led Lynch to suggest other factors at work besides autosomal dominant inheritance, such as cytoplasmic inheritance or virus factors or both. Lynch, Shaw, Magnuson,
}

Larsen, and Krush, op. cit., note 32 above. H T Lynch, Henry M Lemon and Anne J Krush, 'A note on "cancer-susceptible" and "cancer-resistant" genotypes', Nebr. State Med. J., 1966, 51: 209-11.

${ }^{48}$ H T Lynch, P G Rigby, C W Magnuson, A L Larson and A J Krush, 'Etiology of carcinoma: genetic determinism', Nebr. State Med.J., 1966, 51: 8-10, p. 9. 


\section{Henry Lynch, Heredity, and Cancer Control, 1962-1975}

important to the onset of cancer. ${ }^{49}$ But, disentangling the parts played by each member of this symphony orchestra proved a difficult problem. It was quite unclear what was the mode of inheritance, the role of heredity in promoting susceptibility or resistance to cancer, or the relative contributions of heredity and environment. ${ }^{50}$ Lynch saw such problems as mere obstructions to a better understanding of the role of heredity in cancer. The problem for him was that his critics were not persuaded that heredity was a problem significant enough to warrant such investigation; that they worried that Lynch's methods of study might have distorted his results; and that, perhaps, Lynch was himself predisposed to find what he was looking for and so underestimated the significance of other explanations.

As such doubts persisted, Lynch came to believe that they had less to do with science and more to do with the prejudice of major East-coast institutions against a small, mid-western university that challenged the orthodoxy. He, therefore, threw himself back into his research, accumulating more and more empirical data in the hope of changing minds, and publishing the results in a wide range of (sometimes prestigious) journals. ${ }^{51}$ To this end, he turned more and more to Nebraskan institutions and individuals for support. Creighton University gave Lynch considerable freedom to continue his research. ${ }^{52}$ The Omaha-based Eppley Institute funded some of his research when outside monies were hard to get, as did the Nebraska "Aerie" of the Fraternal Order of Eagles. ${ }^{53}$ Nebraskan physicians, Lynch noted, showed themselves enthusiastic about the project, making medical records available, conducting laboratory and physical examinations for the team, donating the use of their facilities and serving as liaisons between the team and the families. ${ }^{54}$ And finally, Nebraskan families-and later families from other stateswelcomed him into their homes, and provided him with data crucial to his research. Critics may have looked down on Nebraska, but Nebraska was to be the saving of Lynch.

\section{Control and Delay}

Lynch was interested not only in identifying hereditary cancers, but also in controlling them. In his view, the identification of such cancers provided new opportunities for

\footnotetext{
${ }^{49}$ Lynch and Krush, op. cit., note 39 above, p. 603.

${ }^{50}$ In his view, susceptibility and resistance worked as a continuum within the population. At one end of the continuum were "cancer families" that had emerged by "selection" with an apparently strong hereditary determinism to cancer. At the other end, were families with little or no cancer, which might indicate hereditary determinism against malignant neoplasia-

"resistance" he called it, with inverted commas.

Lynch, Lemon and Krush, op. cit., note 47 above;

Lynch and Krush, op. cit., note 39 above.

${ }^{51}$ Many of Lynch's publications were in Nebraska's state medical journal. However, he also published in, among other journals, JAMA, Cancer, and the Archives of Internal Medicine. See other notes in this article. Lynch may also have sought to bolster support by, for instance, building alliances with the insurance industry. For example, in a 1971 paper he argued that the life insurance industry should begin to take family histories
}

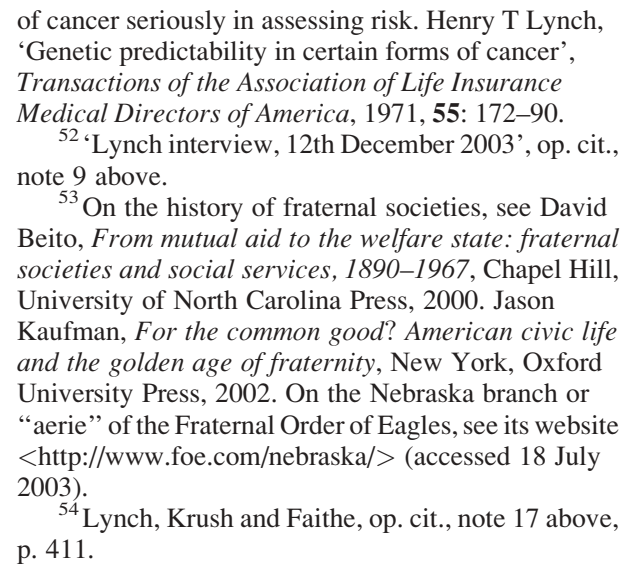

${ }^{53}$ On the history of fraternal societies, see David Beito, From mutual aid to the welfare state: fraternal societies and social services, 1890-1967, Chapel Hill, University of North Carolina Press, 2000. Jason Kaufman, For the common good? American civic life and the golden age of fraternity, New York, Oxford University Press, 2002. On the Nebraska branch or "aerie" of the Fraternal Order of Eagles, see its website $<$ http://www.foe.com/nebraska/> (accessed 18 July 2003).

${ }^{54}$ Lynch, Krush and Faithe, op. cit., note 17 above, p. 411. 


\section{David Cantor}

recognizing the disease early in its development when it could be most effectively treated. The detection of a hereditary cancer in one family member should, he suggested, prompt greater vigilance for the possibility of cancer in others, otherwise "healthy". Yet, if Lynch had hoped that members of cancer families would rush to their physicians at the first sign of what might be the disease, he was often disappointed. Many seemed to avoid seeking help, even if they suspected cancer and knew of relatives with the disease. Indeed, it seemed to Lynch that the presence of cancer in the family might compound the problem. Familial cancers were often regarded as a "disgrace", 55 and individuals delayed not least because of what they had seen it do to others. Thus, Lynch and Krush highlighted the case of one patient-with a huge ulcerating carcinoma involving her entire left breast-who explained: "Though my mother and two sisters had surgery for breast cancer, they died in a horrible way ... I decided to ignore mine as long as possible because there is no hope." 56

Lynch was not the first to note the problem of delay. ${ }^{57}$ Nor was he the first to suggest hereditarian beliefs might compound the problem. For years cancer experts had argued that the popular belief that cancer was hereditary worked against programmes of early detection and treatment by dissuading people from seeking help. Such a belief, they claimed, encouraged fatalism among those who had relatives with cancer, and complacency among those who did not. If heredity did contribute to cancer, they suggested, it contributed such a small amount, that any mention of it might do more damage than good. Consequently, most cancer education programmes invested huge efforts in educating the public in the belief that cancer was not a hereditary disease. ${ }^{58}$ It was, from their perspective, often better to deny bluntly that heredity contributed to cancer, than to risk perpetuating popular misconceptions about it by highlighting its limited role in promoting the disease. ${ }^{59}$ Such

\footnotetext{
${ }^{55}$ Anne J Krush, 'Heredity, emotions, and carcinoma: delay in cancer detection', in Henry T Lynch, Hereditary factors in carcinoma, New York, Springer, 1967, 141-53, p. 146.

${ }^{56}$ Lynch and Krush, op. cit., note 39 above, p. 603. For another example of a patient delaying after witnessing the effect of cancer in another family member, see H T Lynch, T P Krush and Anne Krush, 'Psychodynamics in cancer detection: a patient with advanced cancer of the lip', Psychosomatics, 1966, 7: 152-7.

${ }^{57}$ Aronowitz, op. cit., note 1 above.

${ }^{58} \mathrm{See}$, for example, the dismissal of hereditarian explanations of cancer in the following ACS movies: The traitor within, John Sutherland Productions, 1946; and Man alive, produced by UPA, United Productions of America, 1952, both presented by the American Cancer Society. Copies of both are available in the National Library of Medicine. For early critiques of hereditarian explanations, see 'A war department lecture on cancer', Campaign Notes. American Society for the Control of Cancer, September 1918, 1 (6): [pp. 2-3]. This does not deny that heredity may play a role, but suggests it is only a small factor in the onset of disease. For this reason, it claims that it is not a hereditary disease. George R White, 'The control of
}

cancer', Campaign Notes. American Society for the Control of Cancer, October 1918, 1 (7): [pp. 2-3]; Francis Carter Wood, 'What every woman should know about cancer', Campaign Notes. American Society for the Control of Cancer, January 1919, 1 (9): [pp. 1-4]; Eugene Lyman Fisk, 'A deadly foe routed', Campaign Notes. American Society for the Control of Cancer, February, 19191 (10): [pp. 1-4].

${ }^{59}$ This is not to say that cancer education always ignored the subject of heredity. Some educational pamphlets highlighted animal experiments that suggested a hereditarian component to cancer, only to raise questions about the applicability of such experiments to human cancer. See, for example, Lester Grant, The challenge of cancer: a research story that involves the secret of life itself, Bethesda MD, Federal Security Agency, Public Health Service, National Institutes of Health, 1950; Clarence C Little, The fight on cancer, New York, Public Affairs Committee, 1939, p. 18; and Dallas Johnson for the American Cancer Society and the National Cancer Institute, Facing the facts about cancer, New York, Public Affairs Committee, 1947, pp. 21-3. See also C C Little, 'Research', in Clarence C Little (ed.), Cancer: a study for laymen, New York and Toronto, Farrar \& Rinehart, 1944, pp. 3-46, on pp. 43-4. 


\section{Henry Lynch, Heredity, and Cancer Control, 1962-1975}

attitudes-combined with doubts about Lynch's claim to have identified hereditary cancers-were to prove a major problem for his efforts to promote heredity as a means of improving cancer control. The fact that he himself found that would-be patients delayed because of the stigma and fears generated by familial cancers did not help his case.

Lynch's answer to this quandary focused on devising means of tackling emotional and psychological responses to hereditary cancers (in addition, that is, to his continued efforts to persuade his colleagues of the importance of heredity to human cancer). In his view, such responses were often neglected. Physicians knew little about their patients, still less about their families; education programmes were aimed at the mass rather than the individual; and genetic counselling addressed only the facts of heredity rather than psychological and emotional reactions to the identification of a genetic condition in the family. All this left would-be patients and their families confused, and failed to address the complex factors that promoted delay. It was all too easy, Lynch argued, for control measures to be undermined by the tides of fear, denial, evasion, guilt and apathy that he detected in patients and their families during his field investigations. ${ }^{60}$ Only by a detailed personal knowledge of patients and their families would it be possible to channel individuals to appropriate specialist care; to ensure that they got such care in a timely manner; and that they continued with care during what could be a long, painful and uncertain course of treatment.

Thus, Lynch envisaged a state-wide network of cancer clinics and hospitals; supported by ancillary laboratory, registry and diagnostic facilities; linked by a referral system that passed sick or at-risk patients to appropriate specialist help; and all sustained by public education programmes that encouraged people to seek help. ${ }^{61}$ At the heart of this system was to be the family physician, the gateway to the rest of the network. ${ }^{62}$ In Lynch's view, the family physician was the physician most likely to be aware of cancer in the family; best placed to spot the sometimes subtle early warning signs of the disease; and, as a trusted

As Karen Rader notes, C C Little, head of the ASCC and the Jackson Memorial Laboratory, promoted animal genetic research in his popular publications from the 1930s, but was cautious in applying this work to humans. Anxious that an emphasis on familial cancers might discourage efforts to promote cancer control, Little urged people with cancer in the family to be alert, cautious and intelligent in detecting and reporting cancers, and not to worry. (Rader, op. cit., note 4 above, pp. 194-6.) Such caution is well illustrated by the two pamphlets (above) Little published in 1939 and 1947, the second a revised version of the 1939 pamphlet by Dallas Johnson, an NCI publicity official. Both these pamphlets included accounts of animal experimentation and heredity. But both also included the following caption prominently displayed on the cover: "Did you know: That cancer is NOT hereditary or contagious?" The text inside the 1939 edition warned readers that while a tendency to form cancer might be inherited in humans, it was so indirect that there need not be a source of worry to anyone (p. 18). The discussion inside the 1947 edition was perhaps more cautious about the applicability of mouse experiments to humans. Unlike the 1939 edition, it contained no warnings to people not to worry if cancer in the family was discovered, and the section on heredity (p. 21) concluded with a discussion of mouse experiments that suggested that a virus in the mother's milk might be the cause of cancer. On virus research, see Angela N H Creager and Jean-Paul Gaudillière, 'Experimental platforms and technologies of visualisation: cancer as viral epidemic', in Gaudillière and Löwy (eds), Heredity and infection, op. cit., note 4 above, pp. 203-41; and Gaudillière, 'Circulating mice and viruses', op. cit., note 4 above.

${ }^{60}$ For Lynch and Krush's discussions of emotive responses to cancer, see Krush, Lynch and Magnuson, op. cit., note 22 above; Lynch and Krush, op. cit., note 39 above; Krush, op. cit., note 55 above.

${ }^{61}$ On the creation of such referral systems, see David Cantor, 'Cancer', in Dominique Lecourt, François Delaporte, Patrice Pinell, Christiane Sinding (eds), Dictionnaire de la pensée médicale, Paris, Presses Universitaires de France, 2004, pp. 195-201.

${ }^{62}$ See, for example, the movie Lynch released in 1967 (during his time in Houston) designed to educate family physicians about hereditary cancers and their role in detecting it. The family tree, op. cit., note 25 above. 


\section{David Cantor}

family friend, the best candidate to persuade people to undergo regular screening, to direct them to appropriate specialists if cancer was discovered, and to convince them to stay the course of treatment when the going got tough. His vision was of a network of such physicians across the state (and the country) monitoring (cancer) families, and feeding those affected by the disease to specialist centres where they could get suitable care. ${ }^{63}$

Lynch argued that physicians should "assume the role of both teacher and partner" 64 to their patients. They would correct misconceptions about the disease and heredity; encourage people to seek regular detection examinations; and combat the irrational fears that many individuals had of the disease and heredity. He was particularly hopeful of cancer education at the grade school or early high school level, when the student first encountered science and biology. Teaching students the facts about cancer, he believed, could serve as a platform from which to combat the fear associated with learning about cancer later in adulthood, especially if the early cancer education emphasized the positive aspects of cancer control through early diagnosis. Accordingly, Lynch's department launched a programme in which junior and senior medical students visited local schools to discuss the biological aspects of cancer and its social ramifications. ${ }^{65}$

But physicians could do only so much. Building on his experience in Galveston-where he, Tips, Smith, and McNutt had developed a model of "whole family" or "family centered" genetic counselling ${ }^{66}$ _Lynch argued the case for clinically-trained genetic counsellors to address the problems of hereditary cancer. ${ }^{67}$ In an increasingly specialized and fractured health care system, such a genetic counsellor would, ideally, be someone able to mediate all the information given to patients and their families; provide a more nuanced communication of the nature of disease and heredity; address the families' emotional responses to these efforts; and elicit better information on other family members who might be at risk. Moreover, if the counsellor was also the cancer specialist, he or she could bring together the various medical and social services that the patient and his or her family would need to deal successfully with the problem. Thus, Lynch promoted an "integrative

\footnotetext{
${ }^{63}$ Thus, he instituted a programme to introduce medical students to the reality of disease as it affected people in their homes, and so to encourage empathy with patients. Henry T Lynch, Anne J Krush and Joseph M Holthaus, 'Teaching comprehensive medicine in the home setting: a preliminary report', Nebr. State Med.J., 1969, 54: 454-7, 516-18.

${ }^{64}$ Henry T Lynch and Anne J Krush, 'Early cancer detection is not just the patient's problem', Consultant, 1971, 11 (4): 58-60, p. 59

${ }^{65}$ Henry T Lynch, 'A note on cancer control', Nebr. State Med. J., 1971, 56: 99-100; Lynch and Krush, op. cit., note 64 above.

${ }^{66}$ Tips, Smith, Lynch and McNutt, op. cit., note 14 above; Robert L Tips and Henry T Lynch, 'The impact of genetic counseling upon the family milieu', JAMA, 20 April 1963, 184: 183-6; R L Tips, Henry T Lynch and C Wallace McNutt, 'Genetic counseling', Texas State Journal of Medicine, 1964, 60: 650-3; Henry T Lynch, Robert L Tips, Anne Krush and Charles
}

Magnuson, 'Family centered genetic counseling: role of the physician and the medical genetics clinic', Nebr. State Med. J., 1965, 50: 155-9; H T Lynch, T P Krush, A J Krush and R L Tips, 'Psychodynamics of early hereditary deaths. Role of the medical genetics counselor', Am. J. Dis. Child., 1964, 108: 605-10. See also R L Tips, 'Dynamics of genetic counseling', Eugenics Quarterly, 1962, 9: 237-40; Robert L Tips, George Smith and Donald L Meyer, 'Reproductive failure in families of patients with idiopathic developmental retardation', Pediatrics, 1964, 33: $100-105$.

${ }^{67}$ Henry T Lynch, 'Cancer and genetic counseling', in Lynch, Hereditary factors in carcinoma, op. cit., note 55 above, pp. 154-68. On the dominance of physicians in genetic counselling during this period, see Regina H Kenen, 'Genetic counseling: the development of a new interdisciplinary occupational field', Soc. Sci. Med., 1984, 18: 541-9. See also Ludmerer, op. cit., note 13 above, pp. 174-93. 
psychologic approach" to counselling, providing what he called total medical and psychosocial evaluation and support to a patient and his or her family. ${ }^{68}$ Given contemporary moves in the Nebraska of the late 1960s and early 1970s to promote screening for other genetic conditions there may have been optimism that such a scheme could have been instituted. ${ }^{69}$

\section{Problems}

The rudiments of a system of cancer control had existed in Nebraska since the early 1920s. ${ }^{70}$ But, until Lynch arrived in the state, cancer experts had tended to see hereditarian beliefs as a hindrance to cancer control rather than a help. Part of the problem has already been mentioned: hereditarian beliefs, experts suggested, tended to promote delay, and consequently Nebraskan cancer programmes, like those elsewhere, tended to educate the public in the belief that cancer was not a hereditary disease. But, hereditarian beliefs also raised another problem. Experts worried that they prompted eugenic concerns that cancer control might increase the hereditary burden of cancer, and so might weaken medical and state support for anti-cancer efforts. Thus, for example, in 1939 an editorial in the state medical journal reassured its readers that early cancer detection and treatment would "more than offset such handicaps as heredity may impose". ${ }^{71}$ By the 1960 s, concerns about negative impact of eugenics on cancer control appear to have dissipated; commentators suggested that eugenics was no longer a popular concern. ${ }^{72}$ But for Lynch a new set of problems had emerged.

As relations between eugenics and genetics were reconfigured after the Second World War, attention began to shift towards what Sheldon C Reed, Director of the Dight Institute for Human Genetics, called "non-directive genetic counseling". In non-directive counselling, the genetic counsellor was little more than a purveyor of technical_- "value-free"information on heredity. Reed suggested that the decision of what to do with this information be left to the family rather than to state or other agencies. ${ }^{73}$ Lynch was dismayed by such suggestions. Describing Reed's approach as "cold, mathematical, and stereotyped", 74 he claimed it neither fully characterized the manifold needs of a family with a genetic condition, nor provided insight into how to counsel such families effectively.

${ }^{68}$ On integrative psychological support, see Henry T Lynch, Dynamic genetic counseling for clinicians, Springfield, IL, Charles C Thomas, 1969, esp. ch. 2.

${ }^{69}$ Philip Reilly, 'State supported mass genetic screening programs', in Aubrey Milunsky and George J Annas (eds), Genetics and the law, New York and London, Plenum Press, 1976, pp. 159-94.

${ }^{70}$ P F, 'Cancer week', Nebr. State Med. J., 1921, 6: 290-1; P F, 'Cancer week', Nebr. State Med. J., 1921, 6: 324-5; Palmer Findley, 'The cancer problem', Nebr. State Med. J., 1922, 7: 384-5; 'The 1923 cancer campaign', Nebr. State Med. J., 1923, 8: 412. On the status of cancer control in Nebraska in the 1930s, see Frank Leslie Rector and Clarence Cook Little, 'Report of a cancer survey of Nebraska', Nebr. State Med. J., 1935, 20: 409-42.
71 'Progress in the control of cancer', Nebr. State Med.J., 1939, 24: 138-9, p. 139.

${ }^{72}$ John Baldwin, 'History of the eugenic movement', Nebr. State Med. J., 1962, 47: 458-65.

${ }^{73}$ Sheldon R Reed, Counseling in medical genetics, Philadelphia, Saunders, 1955, pp. 14-15. On Reed and the Dight Institute for Human Genetics, see Paul, op. cit., note 13 above, pp. 133-56. See also Molly Ladd-Taylor, "A kind of genetic social work": Sheldon Reed and the origins of genetic counselling', in Georgina D Feldberg, Molly Ladd-Taylor, Alison Li, and Kathryn McPherson (eds), Women, health and nation: Canada and the United States since 1945, Montreal, McGill-Queen's University Press, 2003, pp. 67-83.

\footnotetext{
${ }^{74}$ Lynch, op. cit., note 67 above, p. 154
} 


\section{David Cantor}

Moreover, Lynch noted, the problems of cancer were very different to those of many other genetic diseases. The principle concern in the case of cancer was not the question of reproductive choice: the real problem was to persuade family members at risk to seek help, and to seek it early. Yet all too often, he argued, individuals seemed to work against their own best interests, risking their own lives by delaying seeking medical attention. In such circumstances, it was insufficient to limit genetic counselling to the transmission of technical information on heredity. The physician had to do more.

For such reasons, Lynch abandoned many of the tenets of non-directive counselling. In his view, the lay public was vulnerable to powerful, even overwhelming (psychodynamic) forces that limited their ability to make rational choices. It followed that physicians were compelled to take greater responsibility for ensuring that they sought help early, and stayed the course of treatment. ${ }^{75}$ It was a medical responsibility to ensure that the cancer control message got through. This is not to say that Lynch argued that patients had no responsibility: indeed, he complained that education programmes were "noticeably weak in emphasizing clearly that it is the patient who must undertake responsibility for his own physical welfare". ${ }^{76}$ Nevertheless, he generally subordinated such arguments to a view of patients and the public as subject to often irresistible forces that limited their capacity to take such responsibility. Such limitations necessitated the active intervention of a physician or counsellor to address the issues that encouraged delay. ${ }^{77}$

Yet almost from the start his scheme encountered difficulties. In the first place, his efforts to address the problem of patients' responses to the diagnosis of a hereditary condition did little to quash medical fears that hereditary conditions might encourage delay and prompt fear. The point was brought home to Lynch in 1977 when critics attacked his call for a national registry system of cancer families to identify patients at risk of the disease, and to help in the estimation of risk for particular target organs. Richard Gatti (Director of the Division of Pediatric Oncology and Immunology at the Cedars-Sinai Medical Center, Los Angeles) argued that such a diagnosis could leave patients quite fearful of the disease. The fact that some in a cancer family who underwent screening did not have cancer was hardly reassuring, since it only opened up the possibility that they might get it in the future. Gatti proposed that further family studies be abandoned until a genetic test was available that could give more certain prognoses. Lynch did himself no favours by responding to Gatti that his experience in Nebraska could act as a model for work elsewhere. As the Harvard paediatrician and human geneticist, Park S Gerald, put it: "what is acceptable in Nebraska may not be acceptable in other parts of the country". 78

Even in Nebraska things did not go as smoothly as Lynch might have wished. Responses to a cancer screening van that he organized in the late 1960s and early 1970s indicate the nature of the problem. "We went around the country, Michigan, all over the place," Lynch

\footnotetext{
${ }^{75}$ Lynch and Krush, op. cit., note 64 above.

${ }^{76}$ Krush, Lynch and Magnuson, op. cit., note 22 above, p. 437.

${ }^{77}$ The importance of physician (and family) intervention to Lynch is well illustrated by his account of one of his early cancer patients, an unnamed farmer-cum-mill worker who came to him and his team around 1965. Lynch, Krush and Krush, op. cit., note 56 above.
}

\footnotetext{
${ }^{78}$ Comments in Henry T Lynch, Jane Lynch and Patrick Lynch, 'Management and control of familial cancer', in John J Mulvihill, Robert W Miller and Joseph F Fraumeni Jr (eds), Genetics of human cancer, progress in cancer research and therapy, volume 3, New York, Raven Press, 1977, pp. 235-56, on p. 255.
} 
recalls, "screening people for cancer. We did pelvic, breast, mouth exams for free. We gave advice to keep healthy, and it was all run by volunteers, by the community."79 Suddenly, however, the state funds for the project dried up. According to Lynch, a group of Nebraskan physicians persuaded a state representative to kill the project. "It was just greed on the part of these doctors because we were providing a free service and they were getting paid for it before," Lynch remembers. "I had just finished doing an exam on this woman and she thanks me and says, "Thank you, doctor. You know, my doctor says you are a communist, but you don't look like a communist!' ",80

More generally, Lynch also came to have doubts about the ability of family physicians to tackle the disease. Despite his hopes that the family physician would channel patients to appropriate care, he complained that they were often ignorant of the disease, overly pessimistic about the possibility of successful treatment, and unwilling to send patients to trained genetic counsellors-so dissuading many would-be patients from seeking or continuing care. How rarely, he felt, they seemed to see the problems of delay and noncompliance as problems requiring active medical intervention-and perhaps in part for practical reasons as much as ignorance. With family physicians increasingly thin on the ground in the 1960s and 1970s, ${ }^{81}$ Lynch and his colleagues complained that low physicianto-patient ratios did not allow sufficient time for the average family physician to practise adequate preventive medicine-including early detection. ${ }^{82}$ In their view, patients were increasingly being left in the dubious hands of the specialist. The fear was that specialists often knew too little about the patient and his or her circumstances; that patients were unable to form close personal relations with them; and that they-the patients-consequently became confused and unable to appreciate fully what was being done for them, sometimes with dire psychological and therapeutic consequences.

To add to these difficulties, Lynch complained that there remained a disturbing ignorance of the psychology of hereditary disease among many physicians, who (inadvertently, perhaps) encouraged fear and despair in their patients by seeking to identify those responsible for the hereditary condition. "This writer and his medical genetic colleagues", Lynch wrote in 1967, "have all too frequently observed the scars and despair of patients who have consulted and been advised by untrained individuals so that they might "clear up this family problem and find out who really is to blame for the hereditary factor'." ${ }^{83}$ Such basic errors of counselling were compounded, he felt, by the Reedian perception of genetic counselling as education in the facts of genetic transmission. Such facts, Lynch argued, might be important to the physician or counsellor, yet they were usually of relatively minor importance to the patient. Patients, he claimed, were more concerned with the emotional

${ }^{79}$ H T Lynch interview with Raul Necochea 7 July 2003, Raul Necochea, report 2, additional or enriched issues in HTL's works based on more recently obtained literature, on literature that links the work of HTL and that of other researchers, on Raul Necochea's field notes from his first trip to Omaha, and on his first interview with HTL July 2003.

${ }^{80}$ Ibid.

${ }^{81}$ Rosemary A Stevens, 'The Americanization of family medicine: contradictions, challenges, and change, 1969-2000', Family Medicine, 2001, 33: $232-43$.

${ }^{82}$ Michael J Haller (Director of the Family Practice Section of Lynch's Department of Preventive Medicine and Public Health), 'The role of the family physicians in the diagnosis and treatment of cancer', in Henry T Lynch (ed.), Cancer and you, Springfield, IL, Charles C Thomas, 1971, 216-25.

${ }^{83}$ Lynch, 'Cancer and genetic counseling', op. cit., note 67 above, p. 157. 


\section{David Cantor}

ramifications and physical consequences of a particular disorder than with formal genetic interpretation. ${ }^{84}$

\section{Families}

It should be clear by now that the family was central to Lynch's vision of cancer control, and in two distinct ways. First, Lynch's approach to cancer control involved an understanding of the family as a hereditary or genetic entity in which certain cancers or pre-cancerous conditions (or predispositions towards such cancers or pre-cancerous conditions) passed from one generation to another, the actual occurrence of cancer being the product of specific (albeit unknown) conjunctions of environmental and genetic factors, and predicted by means of statistical probabilities derived from family studies. From such a perspective, Lynch argued that the identification of a hereditary cancer in one member of a family should, ideally, be followed both by attempts to persuade that individual to seek early treatment, and by the surveillance of healthy members of his or her family so as to increase opportunities for spotting the disease at a stage in its development most amenable to treatment.

Second, Lynch's approach to cancer control involved an understanding of the family as a psychosocial entity, easily disturbed by the disease, the diagnosis, or the interventions against it. In Lynch's view, the diagnosis of a hereditary cancer often generated complex and sometimes conflicting responses that had to be understood in the context of the beliefs, attitudes and patterns of emotional and mental interaction specific to individual families. People delayed seeking medical attention, abandoned promising therapies, turned to "quacks", and risked economic ruin or a wrecked marriage rather than seek assistance. They also developed strange and disturbing behaviours, such as that of the man who forced his children to kiss him full on his tumorous lip: ${ }^{85}$ behaviours that deeply upset other family members and so exacerbated psychological and social problems related to the disease. All these self-destructive problems could be explained, at least in part, by reference to the family circumstance. "Genetic problems are family problems," Lynch wrote, "and are often steeped with anxiety, guilt, fear, hostility, apprehension, ambivalence and misconceptions." 86

The family was thus a double threat to its individual members, and hence to efforts to promote cancer control. In Lynch's view, it was not only a carrier of hereditary disease. It was also the carrier of beliefs, attitudes and patterns of emotional and mental interaction that shaped - consciously or unconsciously - individual responses to the disease. Deborah Weinstein has shown that post-war family therapists increasingly saw mental illness as rooted in patterns of family interactions rather than the biological or psychological

\footnotetext{
${ }^{84}$ Ibid., pp. 165-6.

${ }^{85}$ Lynch, Krush and Krush, op. cit., note 56 above. The children in this case were repulsed by the sight and
}

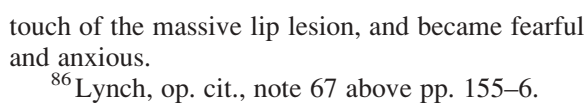

${ }^{86}$ Lynch, op. cit., note 67 above pp. 155-6. 


\section{Henry Lynch, Heredity, and Cancer Control, 1962-1975}

characteristics of the individual. ${ }^{87}$ Lynch saw similar roots to the many psychological and social problems that followed the diagnosis of hereditary cancer. In his view, it followed that it was impossible to treat the hereditary disease without addressing the family situation.

The problem for Lynch was that cancer control programmes rarely tackled such situations. They failed to view the family as a carrier of hereditary cancers, and so failed to target family members at risk of the disease. They also failed to view the family as a psychosocial entity, and so failed to target familial difficulties that promoted delay, noncompliance, or disruptive behaviours. In consequence, Lynch argued these programmes contributed to what he called physician delay - the failure of physicians to recognize the seriousness of the problem - as important an issue as patient delay, he claimed. ${ }^{88}$ In Lynch's view, control programmes needed to educate physicians about their own contributions to delay and other problems, and, indeed, to begin to take a much more interventionist approach to cancer control. As noted earlier, he argued that it was not sufficient to place responsibility solely on the patient to seek medical assistance: people were easily overwhelmed by the cancer or their family's response to it. Physicians had a responsibility to help them overcome mental and emotional barriers to care. They also had a responsibility to help them overcome the social, racial, ethnic, occupational and socio-economic factors that promoted delay and non-compliance. ${ }^{89}$ Such responsibilities should, in Lynch's view, be part of any programme of cancer control.

In his efforts to promote such medical responsibilities, Lynch turned for inspiration to an imagined older world of medicine, untainted by the increasing tendency he detected of physicians to limit their own responsibilities and so abandon patients to their own resources. ${ }^{90}$ His image of the family physician as friend and confidant to the family harkened back to a mythic golden age of family practice now sadly almost gone. In this imagined era, physicians, patients and families were bound together in complex, long-term, evolving sets of relationships that made it quite impossible for physicians to treat only the disease. Physicians brought their patients into the world, treated their childhood ailments, and saw them develop through adolescence, and into adulthood and old age. They treated their parents, siblings, spouses and children. They were physicians to the family as much as the individual patient, important figures in the local community, wellplaced to address the complex familial and social issues that illness could create. These were the foundations upon which Lynch hoped to build a new programme of cancer

\footnotetext{
${ }^{87}$ Deborah F Weinstein, 'Culture at work: family therapy and the culture concept in post-World War II America', J. Hist. Behav. Sci., 2004, 40: 23-46; Deborah Fran Weinstein, 'The pathological family: a cultural history of family therapy in post-World War II America', PhD thesis, Harvard University, 2002.

${ }^{88}$ Henry T Lynch and Anne J Krush, 'Attitudes and delay in cancer detection', CA: Cancer Journal for Clinicians, 1968, 18: 287-93.

${ }^{89}$ For example, he speculated that the western tradition of independence and self-reliance among the white Nebraskan rural population encouraged excessive feelings and beliefs of self-sufficiency. All
}

too often, he noted, Nebraskans used their own resources to defray the costs of illness, even to the point of destitution. Traditions of self-reliance, he noted, contributed to a lack of knowledge of the resources available through state, federal and community agencies. Krush, Lynch and Magnuson, op. cit., note 22 above, p. 436.

${ }^{90}$ There are strong parallels between Lynch's critique of narrow specialization and that of early twentieth-century holists, see Christopher Lawrence and George Weisz (eds), Greater than the parts: holism in biomedicine, 1920-1950, New York and Oxford, Oxford University Press, 1998. 


\section{David Cantor}

control, reinforced by the newer insights of medical genetics, "whole family therapy" and "integrative psychologic approaches" to counselling. Control, in Lynch's imagination, involved a return to an older set of community values, in which family physicians took greater responsibility for their patients' welfare, watched them for signs of ill-health, and intervened as only a trusted friend could when things seemed awry. Here was a vision of "surveillance medicine" $"$ built on the social relations, medical practices, and ethics of an imagined earlier age.

The family physician was thus the symbolic moral core of the cancer control system that Lynch hoped to develop; a figure who blended the values of an older world of medicine, with those of modern science. Lynch would have been the first to admit that in practice physicians often did not meet such lofty values. Rather, the figure of the family physician served to help construct a model of care and responsibility to which cancer control programmes (and physicians within them) could aspire. In such programmes, the family physician was, as we have already noted, to be a gatekeeper to the cancer control system. But, he or she was also to be its ethical heart, someone who not only referred patients to others within the system, but whose values and approach permeated practice across the system. Cancer specialists, medical geneticists, and genetic counsellors all had to adopt something of the approach of the family physician. They had to know their patients and their families in all their complexity, and to take more of the responsibility for helping them seek medical assistance, and stay the course of treatment.

Indeed, at one point Lynch argued that because of an acute shortage of professionally trained genetic counsellors, family physicians should assume much of the responsibility for counselling. ${ }^{92}$ In his view, the practice of genetic counselling had many parallels with the work of the family physician. It involved the traditional physician-patient relationship of "intimacy and confidence". ${ }^{93}$ Ideally, it sought to address the mental and emotional sides of illness, as much as it addressed the biological side. It was less a science than an art. It involved the acquisition of a broad, intimate knowledge of the patient and his or her circumstances; an incommunicable knowledge, something "one could not possibly hope to describe ... in words". ${ }^{94}$ In genetic counselling, as in family medicine, nothing substituted for the ineffable experience of working face-to-face with patients. ${ }^{95}$ It will

\footnotetext{
${ }^{91}$ On surveillance medicine, see David Armstrong, 'The rise of surveillance medicine', Sociology of Health and Illness, 1995, 17: 393-404.

${ }^{92}$ Henry T Lynch, Gabriel M Mulcahy, and Anne J Krush, 'Genetic counseling and the physician', JAMA, 1970, 211: 647-51, p. 651. On Lynch's view of the role of the physician in genetic counselling, see also Henry T Lynch and Anne J Krush, 'Genetic counseling and cancer: implications for cancer control', Southern Medical Journal, 1968, 61: 265-9; Henry T Lynch, Gabriel M Mulcahy, and Anne J Krush, 'Genetic counseling (A scientific exhibit)', Nebr. State Med.J., 1970, 55: 209-16. Regina Kenen has noted that genetic counselling in the 1950s and 1960s was dominated by physician practitioners: Lynch vigorously argued that
}

this was a desirable state of affairs. Kenen, op. cit., note 67 above.

${ }^{93}$ Lynch, op. cit., note 67 above p. 155.

${ }^{94}$ Ibid.

${ }^{95}$ On clinical attitudes to language in the British context, see David Cantor, 'The NAME and the WORD: Neo-Hippocratism and language in inter-war Britain', in David Cantor (ed.), Reinventing Hippocrates, Aldershot, Ashgate, 2001, pp. 280-301; Christopher Lawrence, 'Incommunicable knowledge: science, technology and the clinical art in Britain 1850-1914', J. Contemp. Hist., 1985, 20: 503-20. 


\section{Henry Lynch, Heredity, and Cancer Control, 1962-1975}

be recalled that Lynch also suggested that the cancer specialist should assume responsibility for counselling. But in Lynch's vision of cancer control, this was a specialist who shared many of the values of the family physician. Distinguished by his or her greater knowledge of the disease and its management, this imagined specialist (like the family physician) sought to integrate the medical, social and psychological care of the patient and his or her family. How different this was to the current world of cancer control, where physicians rarely knew their patients well, let alone their families, and so failed to understand or address their emotional and mental responses to hereditary cancers.

Yet it was an uphill struggle to promote this approach to cancer control. The methods Lynch proposed to identify familial pathologies were undermined by the problems of family medicine; by the enthusiasm for "non-directive" counselling; by doubts about the significance of heredity to human cancers; by the contemporary enthusiasm for viral and environmental explanations for cancer; and, perhaps, by a reluctance on the part of many physicians to take the level of responsibility that Lynch advocated for ensuring that their patients did not delay. Nor were Lynch's proposals helped by his own location in a minor educational institution, in (to the eyes of the cancer establishment) a remote part of the country. In the 1960s and 1970s, Lynch was simply unable to persuade most physicians and geneticists that he had identified a significant hereditary component to human cancer, or that this might provide the basis of a new approach to cancer control.

Lynch's marginal position would not begin to change until the identification of the first cancer genes in the 1990s, when his collection of family histories would become important to molecular work on the genetics of some cancers. ${ }^{96}$ After years in the wilderness, Lynch was to see widespread acceptance of the genetic nature of a number of "his" cancers, albeit a genetic nature quite different to that which he had originally imagined. ${ }^{97}$ This is not to say that the new geneticists wholly embraced Lynch. It is true that he was eventually honoured with having a number of familial, cancerous syndromes named after

\footnotetext{
${ }^{96}$ On the identification of cancer genes, see Kevin Davies and Michael White, Breakthrough: the race to find the breast cancer gene, New York, John Wiley, 1996. For an account of longer history of the molecularizing of cancer research, see Jean-Paul Gaudillière, 'The molecularization of cancer etiology in the postwar United States: instruments, politics and management', in Soraya de Chadarevian and Harmke Kamminga (eds.), Molecularizing biology and medicine: new practices and alliances, 1910s-1970s, Amsterdam, Harwood, 1998, pp. 139-70. On the impact of molecular genetics on HNPCC, see Raul Antonio Necochea, 'From cancer families to HNPCC: Henry Lynch and the transformations of hereditary cancer, 1975-1999', Bull. Hist. Med., in press.

${ }^{97}$ Nevertheless, there remained a complex relationship between molecular biological and
}

older notions of genetics. For example, in the 1990s, molecular biologists began to conceptualize HNPCC not as a disease that ran in families, but one with specific genetic components that could be detected by genetic testing. However, the search for HNPCC genes was in part dependent on the prior identification by means of family studies of entities called "cancer families", and the diagnosis of HNPCC required that mutated genes be found within a kin group identified as a "cancer family". Genetic testing did not do away with older notions of the "cancer family". See Necochea, op. cit., note 96 above. 


\section{David Cantor}

him. ${ }^{98}$ But suspicions remained that he had bargained his way into the molecular genetic revolution with a resource-extensive family records - that molecular geneticists needed for their studies, but that he did not have the technical skill or scientific credentials necessary to take such research forward. Some critics also continued-and still continue- to regard his early work on heredity as dubious science. The irony of Lynch is that while he came to be honoured as the one of the "fathers" of cancer genetics, his "children" sometimes quietly questioned his paternity. ${ }^{99}$

\footnotetext{
${ }^{98}$ Three syndromes are named after him: Lynch's syndromes I and II (syndromes involving a familial predisposition to colorectal cancer), and Lynch-Wiersma syndrome (a combination of ichtyosis congenita and secondary male hypogonadismus).
} 